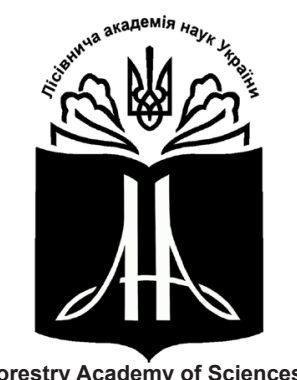

Forestry Academy of Sciences of Ukraine
Наукові праці Лісівничої академії наук України Proceedings of the Forestry Academy of Sciences of Ukraine http://fasu.nltu.edu.ua

https://doi.org/10.15421/411814

Article received 2018.02.20

Article accepted 2018.05.31
ISSN 1991-606X print

ISSN 2616-5015 online

(a) $\triangle$ Correspondence author

Igor Litsur

ilytsur@ukr.net
Taras Shevchenko boulevard 60, Kyiv, 01032, Ukraine

УДК 330.1: 630.23

\title{
Аналіз фінансування видатків підприємств Держлісагенства з державного бюджету України
}

\author{
А.І. Карпук' ${ }^{1}$ І. М. Лицур²
}

Досліджено сутність та особливості механізму фіскального регулювання, обтрунтовано науково-теоретичні засади його впливу на забезпечення збалансованого розвитку лісового господарства в системі фіскальної політики природокористування.

Проаналізовано стан фіскального регулювання в досліджуваній сфері та виявлено, шзо зниження фінансової стабільності лісогосподарських підприємств негативно впливає не лише на фінансово-економічну, але й на соціальну, екологічну ситуацію, продуктивність лісових екосистем, спричиняє погіршення сортиментної структури деревини, втрату нею конкурентоспроможності на ринку. Основними причинами нестачі коштів бюджетів різних рівнів визначено: низьку частку власних дохідних коштів, залежність від державного фінансування, відсутність стимулів щзодо додаткового одержання доходів та економного витрачання бюджетних коштів. За умови ефективної організаиії внутрішньогалузевої взаємодії можливо мінімізувати бюджетну підтримку та функціонувати на засадах самоокупності, збільшивщи надходження до бюджетів усіх рівнів.

Обгрунтовано залежність наповнення бюджету $і$ подальшого процесу перерозподілу доходів між бюджетами різних рівнів та, як наслідок, збалансованого розвитку лісового господарства, від обсягу податкових надходжень і ефективності застосування інструментів фіскального регулювання. Для поліпшення реалізації лісової політики існує необхідність поліпшити наповнення бюджетів усіх рівнів, щзо передбачає застосування таких інструментів, які є найбільш дієвими і не вимагають додаткових витрат з бюджету, з одного боку, $і$ не знижують показників діяльності лісогосподарських підприємств - з іншого.

Запропоновано кониептуальні засади функиіонування механізму фіскального регулювання з урахуванням світового досвіду.

Ключові слова: фіскальне регулювання; лісо господарювання; лісові ресурси; податкове навантаження.

Вступ. Важливою складовою економічного регулювання збалансованого та невиснажливого лісокористування є механізм фіскального регулювання. Основними інструментами фіскального регулювання є доходи та видатки, які є бюджетними та податковими складовими. Більшість розвинутих країн в системі заходів антикризового регулювання економіки використовують інструменти фіскального ре- гулювання не лише для вирішення фіскальних цілей, але й для виконання невідкладних завдань суспільного розвитку, перерозподілу доходів бюджетів між державою, економічними суб'єктами та населенням, а також для забезпечення стимулювання раціонального використання природних ресурсів.

Зниження фінансової стабільності лісогосподарських підприємств призводить не лише до нега-

\footnotetext{
Карпук Анатолій Іванович - дійсний член Лісівничої академії наук України, доктор економічних наук, директор відокремленого підрозділу Національного університету біоресурсів і природокористування України «Боярська ЛДС», вул. Лісодослідна 12, м. Боярка, 08150, Україна. Тел.: 045-983-54-61. E-mail: vp_nau_blds@ukr.net

2 Лииур Ігор Миколайович - член-кореспондент Лісівничої академії наук України, доктор економічних наук, провідний науковий співробітник Державної установи «Інститут економіки природокористування та сталого розвитку Національної академії наук України», бульвар Тараса Шевченка 60, м. Київ, 01032, Україна. Тел.: 044-486-40-25, +38-096-438-34-75. E-mail: ilytsur@ukr.net
} 
тивних фінансово-економічних наслідків, але й соціальних та екологічних, негативно відображається на продуктивності лісових екосистем, зниженні рівня біорізноманіття, погіршенні сортиментної структури деревини, втраті конкурентоспроможності ㄲi на ринку. Основними причинами нестачі коштів бюджетів різних рівнів є низька частка власних дохідних коштів, залежність від державного фінансування, відсутність стимулів у додатковому одержанні доходів та нецільове витрачання бюджетних коштів. Такий стан ведення лісового господарства не повністю задовольняє основним вимогам чинного природоохоронного законодавства щодо збереження, комплексного та ефективного використання і примноження лісових ресурсів.

Теоретико-методологічні засади фіскального регулювання спеціального використання природних ресурсів, актуальні питання рентного регулювання розглянуто в численних наукових працях (Turkevich, 1977, Antonenko, 2001, Savushchyk, Poliakova, \& Popov, 2001, Shvydenko, 2004, Dubas, 2011, Tunytsia, 2011, Khvesik, Shubaliy, \& Vasilik, 2011, Shershun, 2012, Furdichko \& Bobko, 2013, Bobko, 2014). Поряд 3 цим, недостатньо уваги приділено питанням теоретичного обгрунтування механізму фіскального регулювання у лісовому господарстві та його складових.

Об'єкт та методика досліджень. Об ' $\epsilon$ жm дослідження - процес фіскального регулювання в лісовому господарстві. Предмет дослідження - сукупність теоретико-методологічних підходів і практичних рекомендацій, спрямованих на вдосконалення механізму фіскального регулювання у лісовому господарстві.

Мета досліджень - поглиблення теоретичних i розробка методологічних підходів до формування механізму фіскального регулювання у лісогосподарській сфері.

Теоретичну та методологічну основу дослідження становлять фундаментальні положення економічної теорії, економіки природокористування та охорони навколишнього природного середовища, праці провідних вітчизняних і зарубіжних учених 3 проблем формування механізму фіскального регулювання у лісовому господарстві. Виконання окреслених у роботі завдань здійснювалось 3 використанням сучасних методів дослідження, зокрема абстрактно-логічного - для з'ясування сутності фіскального механізму регулювання лісового господарства; економіко-статистичного - для аналізу сучасного стану фінансування видатків підприємств Держлісагенства 3 державного бюджету України; системно-структурного та порівняльного аналізу - для теоретичного узагальнення сучасних наукових досліджень у галузі соціальноекономічних відносин, що виникають у результаті податкового навантаження на економічну діяльність лісогосподарських підприємств; кореляиійнорегресійного аналізу - для оцінки структури і динаміки доходів галузі у складі бюджету України; розрахункового $i$ графічного - для обгрунтування ефективності функціонування механізму фіскального регулювання у забезпеченні збалансованого розвитку лісового господарства.

Результати та обговорення. Основними джерелами фінансування розвитку лісового господарства $€$ кошти державного та місцевих бюджетів лісокористувачів, а також інших джерел, у т. ч. коштів міжнародних організацій та іноземних інвесторів. Видатки на підвищення продуктивності, поліпшення якісного складу лісів, їх відтворення і охорони згідно ст. 98 Лісового кодексу (Forest code of Ukraine, $1994)$ здійснюються за рахунок державного бюджету та власних коштів підприємств, установ і організацій лісового господарства (щодо лісів державної власності); місцевого бюджету і власних коштів підприємств, установ та організацій лісового господарства (щодо лісів комунальної власності) і власних коштів власників лісів (щодо лісів приватної власності). Видатки на підвищення продуктивності, поліпшення якісного складу лісів державної і комунальної власності, їх охорону, захист і відтворення фінансуються шляхом цільового виділення коштів 3 державного та місцевих бюджетів для реалізації загальнодержавних, державних і регіональних (місцевих) програм ведення лісового господарства.

Лісовий сектор належить до тих ланок національної економіки, який за умови ефективної організації внутрішньогалузевої взаємодії може мінімізувати бюджетну підтримку та працювати на засадах самоокупності, збільшивши надходження до бюджетів усіх рівнів. У теперішній складній економічній ситуації основна увага повинна бути спрямована на реалізацію тих пропозицій, які забезпечують зміни у базових законодавчо-нормативних актах i передбачають застосування податкових i неподаткових регуляторів господарського освоєння природно-ресурсного потенціалу. Природні та соціально-економічні умови зумовлюють суттєву різницю в економічних показниках лісових господарств в окремих природних зонах. 3 метою визначення тенденцій використання бюджетних коштів та виявлення, які саме інструменти фіскального механізму можуть забезпечити збалансований розвиток лісового господарства, важливим аспектом є аналіз динаміки і структури фінансування видатків на ведення лісового господарства. Аналіз складових елементів механізму фіскального регулювання вказує на необхідність фінансування видатків лісової галузі за функціональною класифікацією «Ведення лісового і мисливського господарства, охорона і захист лісів» (табл. 1).

Удосконалення інструментів механізму фіскального регулювання повинно підвищити конкурентоспроможність лісової галузі України, активізувати інноваційно-інвестиційну складову іiі розвитку, позитивно вплинути на структурні процеси у лісовому господарстві, тим самим забезпечивши динамічне економічне зростання із підвищенням рівня та якості життя населення загалом.

Однією 3 важливих причин нераціонального використання лісових ресурсів $є$ недосконалість 
фінансового механізму, відсутність інвестицій на лісовідновлення та проведення інших екологічно орієнтованих заходів. Оскільки лісове господарство здійснює природоохоронну діяльність, а лісові ресурси продукують позитивні внутрішні і зовнішні ефекти, то для забезпечення галузі необхідними фінансовими ресурсами в складі фінансового механізму необхідно передбачити методи стимулювання процесів лісокористування, до яких відносяться пільгове оподаткування, бюджетне фінансування, пільгове кредитування (Ilnytska-Hykavchuk \& Rymar, 2006). Фінансування заходів 3 підвищення продуктивності, поліпшення якісного складу лісів, їх охорони, захисту і відтворення здійснюються за рахунок державного бюджету та власних коштів підприємств, установ і організацій щодо лісів державної власності; відповідні видатки фінансуються шляхом цільового виділення коштів Державного бюджету для реалізації загальнодержавних, державних і регіональних (місцевих) програм ведення лісового господарства. Суттєвим елементом нарощення обсягів фінансових потоків на підприємствах лісового господарства є створення регіонального фонду відтворення, охорони та захисту лісів, що певним чином може спростити рух фінансових потоків відповідно до їх цільового призначення (Bakaleiko \& Volynchuk, 2014).

Динаміка і структура фінансування державних підприємств Держлісагенства України впродовж 2010-2016 рр.

\begin{tabular}{|c|c|c|c|c|c|c|c|c|}
\hline Показник & 2010 & 2011 & 2012 & 2013 & 2014 & 2015 & 2016 & $\begin{array}{l}2016 \text { до } \\
2010, \pm\end{array}$ \\
\hline \multicolumn{9}{|c|}{ Видатки } \\
\hline Держлісагенство, усього, млн грн & 613,60 & 751,71 & 657,22 & 695,59 & 511,41 & 462,14 & 137,45 & $-492,74$ \\
\hline Питома вага у Державому бюджеті, \% & 0,199 & 0,219 & 0,159 & 0,166 & 0,116 & 0,079 & 0,020 & - \\
\hline $\begin{array}{l}\text { У т.ч. на ведення лісового } \\
\text { господарства, млн грн }\end{array}$ & 374,93 & 491,05 & 602,20 & 640,57 & 460,80 & 412,72 & 79,85 & $-308,68$ \\
\hline $\begin{array}{l}\text { Питома вага на ведення лісового } \\
\text { господарства, \% }\end{array}$ & 61,10 & 65,32 & 91,63 & 92,09 & 90,10 & 89,31 & 58,09 & - \\
\hline Споживання, млн грн & 503,21 & 539,93 & 530,77 & 119,36 & 109,24 & 115,98 & 126,74 & $-246,09$ \\
\hline Питома вага, \% & 82,01 & 71,83 & 80,76 & 17,16 & 21,36 & 25,10 & 92,21 & - \\
\hline Розвитку, млн грн & 110,38 & 211,78 & 126,45 & 576,23 & 402,17 & 346,16 & 10,71 & 8,62 \\
\hline Питома вага, \% & 17,99 & 28,17 & 19,24 & 82,84 & 78,64 & 74,90 & 7,79 & - \\
\hline \multicolumn{9}{|c|}{ Доходи } \\
\hline $\begin{array}{l}\text { Рентна плата за спецвикористання } \\
\text { лісових ресурсів до Держбюджету, } \\
\text { млн грн }\end{array}$ & 156,60 & 161,90 & 182,50 & 201,00 & 334,80 & 431,40 & 461,90 & 305,30 \\
\hline Питома вага у Дербюджеті краӥни, \% & 0,061 & 0,053 & 0,049 & 0,057 & 0,089 & 0,083 & 0,075 & - \\
\hline $\begin{array}{l}\text { Рентна плата за спецвикористання } \\
\text { лісових ресурсів до місцевого бюджету, } \\
\text { млн грн }\end{array}$ & 14,00 & 61,00 & 82,40 & 105,50 & 212,90 & 309,20 & 456,00 & 442,00 \\
\hline Питома вага у місиевому бюджеті, \% & 0,020 & 0,080 & 0,093 & 0,114 & 0,239 & 0,257 & 0,267 & - \\
\hline $\begin{array}{l}\text { Сплачено податків та внесків } \\
\text { до Зведеного бюджету, млн грн }\end{array}$ & 1151,50 & 1327,50 & 1372,20 & 1498,60 & 1972,70 & 3159,60 & 4207,90 & 3056,40 \\
\hline $\begin{array}{l}\text { Питома вага податкових платежів } \\
\text { та внесків, \% }\end{array}$ & 0,378 & 0,342 & 0,317 & 0,349 & 0,444 & 0,485 & 0,538 & - \\
\hline
\end{tabular}

Джерело: розраховано І.М. Лииуром на основі законів про Державний бюджет Украйни (2010-2016 рр.) та за даними Державного агентства лісових ресурсів Украӥни

Перейдімо до аналізу стану фінансування лісової галузі в Україні. Починаючи з 2010 р., обсяг видатків Державного бюджету країни значно зріс, порівняно з попередніми роками, було значно вищим фінансування лісової галузі. Однак частка видатків 3 бюджету на фінансування Держлісагентства у структурі Державного бюджету значно скоротилась (рис. 1).
Також важливим чинником $є$ різка тенденція зміни пріоритетності фінансування видатків споживання над видатками розвитку у лісовій галу3i. Зокрема, у 2016 р. видатки розвитку становили $7,8 \%$ у загальній частині фінансування, що на 327,8 млн грн менше, ніж у 2015 році. На рис. 2 наведена структура видатків Державного бюджету України в період 2015-2016 pp. 


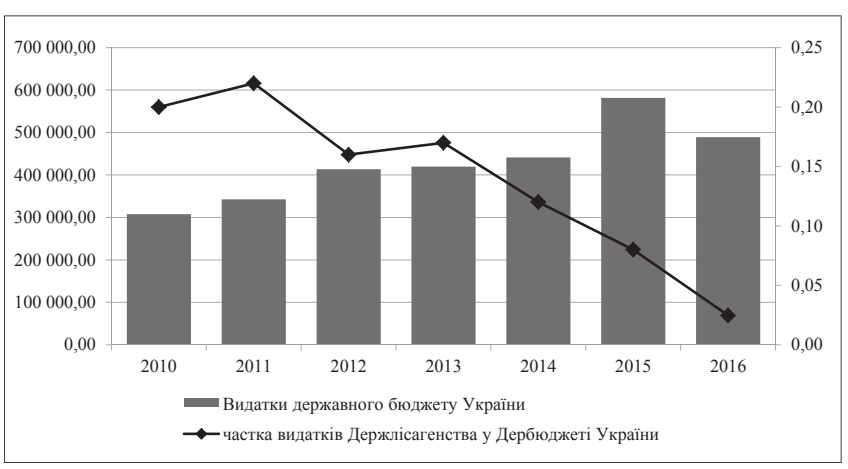

Рис. 1. Динаміка частки видатків Державного лісового агентства України у структурі видатків Державного бюджету України, 2010-2016 рр.

Джерело: за даними Закону про державний бюджет Украӥни, 2010-2016 рр.

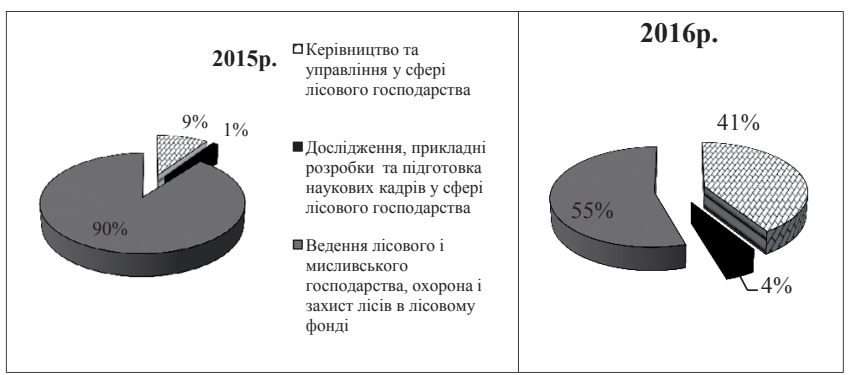

Рис. 2. Порівняння структури фінансування видатків Держлісагенства України з Державного бюджету України

Джерело: за даними Державного агентства лісових ресурсів України

Останніми роками спостерігається різка негативна тенденція значимості видатків на лісову галузь у видатках Державного бюджету України. Частка видатків на Держлісагентство у структурі Державного бюджету України зменшилась $30,2 \%$ у 2010 до $0,02 \%$ у 2016 році. Спадна тенденція розпочалась 32012 р., і в 2016 р. стала критичною порівняно з 2015 р. частка видатків зменшилась на $0,06 \%$. Хоча питома вага фінансування галузі у відсотках зовсім низька, для галузі ці зміни відчутно помітні. Найбільшу суму видатків на Держлісагенство $з$ державного бюджету за аналізований період зафіксовано у 2011 р. - 751,7 млн грн, а найменшу у 2016 - 120,9 млн грн, що на 492,7 млн грн менше порівняно з 2010 роком. Така ситуація пов'язана, насамперед, із загальною економічною ситуацією в країні та воєнними діями на сході.

Одним 3 найбільш пріоритетних та важливих показників видатків лісової галузі за функціональною класифікацією $є$ стаття «Ведення лісового і мисливського господарства, охорона і захист лісів в лісовому фонді». Адже, головною метою ведення лісового господарства $є$ відтворення та збереження лісів, підвищення їх продуктивності, лісорозведення, збереження робочих місць. Фінансування цієї статті видатків становило 66,3 млн грн у 2016 р., що на 308,7 млн грн менше ніж у 2010 році. Однак серйозне занепокоєння щодо фінансування цієї статті свідчить порівняння його обсягу з таким у 2015 р.: зменшення склало 332,9 млн грн.

Починаючи з 2010 р. фінансування цієї статті видатків збільшувалось до 2013 р., однак з 2014 р. вже спостережено негативну тенденцію (рис. 3). Різке зменшення цієї статті видатків спостерігаємо 3 2014 р., основними причинами чого стали військові дії та політико-економічна криза у державі. Питома вага видатків на ведення лісового господарства у 2016 р. порівняно з 2013 р. зменшилась на 37,3\%, а з 2015 - на 34,5\%. У 2016 р. динаміка зменшення фінансування склала $43,74 \%$.

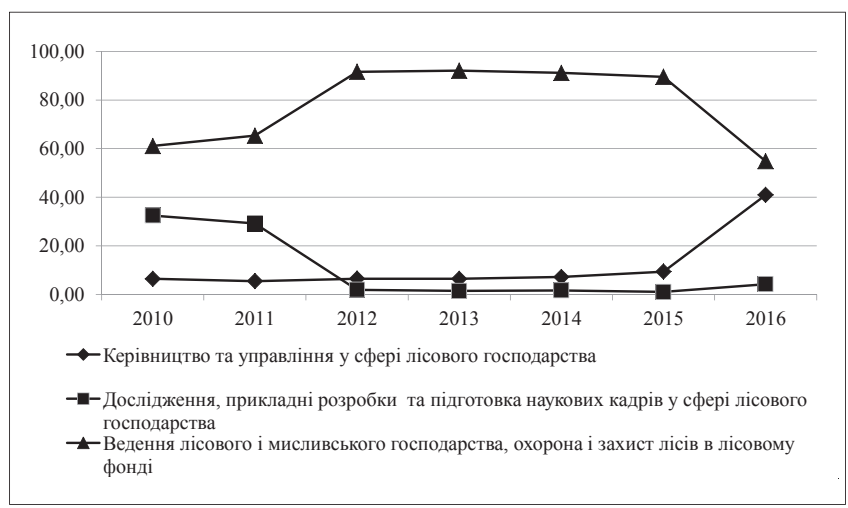

Рис. 3. Динаміка частки видатків у структурі видатків Держлісагенства з Державного бюджету України впродовж 2010-2016 pp.

Джерело: за даними Державного агентства лісових ресурсів України

Така зміна спричинена збільшенням у структурі фінансування статті видатків, що має назву «Керівництво та управління у сфері лісового господарства». Цей показник впродовж аналізованого періоду мав відносно стабільну тенденцію у структурі видатків - від 6,43 до 9,40\%, однак у 2016 р. частка цього показника стрімко зросла і склала $40,95 \%$.

Обсяг коштів, які спрямовані на ведення лісового господарства у розрізі обласних управлінь лісового і мисливського господарства (ОУЛМГ) представлено на рис 4. Отже, підприємства, які знаходяться на лісистих територіях, вже перейшли на самостійне фінансування, за рахунок власних коштів ведуть лісогосподарську діяльність. Проблематичним $є$ ведення лісового господарства у південному і східному регіонах України, де підприємства не мають власних коштів, а держава не фінансує в повному обсязі необхідні видатки. Такий стан виявляє негативний вплив на охорону і захист лісів у цих регіонах, оскільки на півдні і сході країни ліси відіграють надзвичайно важливу роль у захисті довкілля, що сприяє ефективному веденню сільського господарства.

Також у структурі фінансування видатків Держлісагенства 3 державного бюджету має місце бюджетна програма «Дослідження, прикладні розробки та підготовка наукових кадрів у сфері лісового господарства», частка якої у 2012 р. становила $1,89 \%$ у структурі видатків, що на $30,6 \%$ менше порівняно 32010 роком. На дослідження, прикладні 
розробки та підготовку наукових кадрів у сфері лісового господарства спрямовується 1,05\% у 2015 р. та 4,24\% - у 2016 р. бюджетних коштів: зафіксовано збільшення на 449, 3 тис грн.

Структура фінансування ОУЛМГ на ведення лісового господарства представлена на рис. 5.

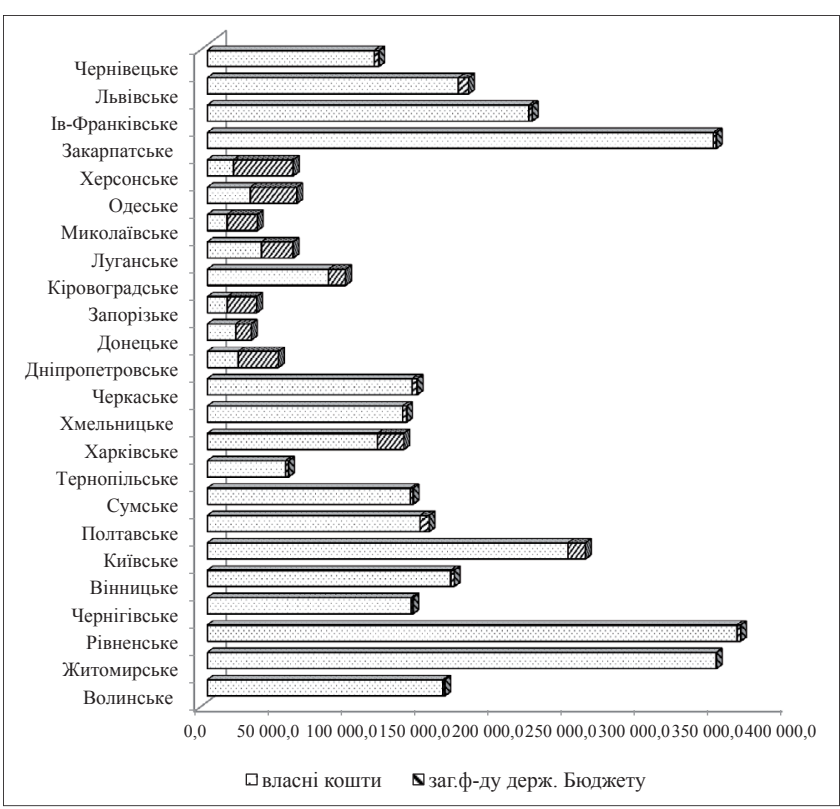

Рис. 4. Обсяг коштів, спрямованих на ведення лісового господарства у розрізі ОУЛМГ за 2015 р., тис. грн Джерело: за даними Державного агентства лісових ресурсів України

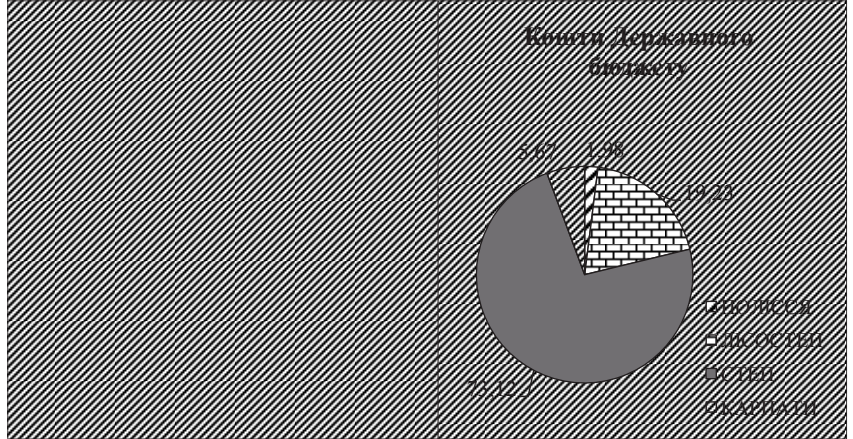

Рис. 5. Структура розподілу коштів фінансування ведення лісового господарства у розрізі природних зон, 2015 р., тис. грн

Джерело: за даними Державного агентства лісових ресурсів України

Природні та соціально-економічні умови зумовлюють суттєву відмінність в економічних показниках лісових господарств окремих природних зон: регіони, краще забезпечені лісовими ресурсами, спрямовують більше власних коштів на ведення лісового господарства.

На цей час основним джерелом ведення лісового господарства загалом по Україні є власні кошти підприємств, які формуються від реалізації продукції лісозаготівель. Впродовж 2010-2016 рр. частка від цієї діяльності постійно змінювалась, досягнувши рівня 98,5\% від загальних обсягів реалізованої продукції, робіт та послуг лісового господарства (табл. 2).

Таблиця 2

\section{Динаміка та структура витрат на ведення лісового і мисливського господарства, охорону} і захист лісів в Україні впродовж 2010-2016 рр.

\begin{tabular}{lccccccc}
\hline \multicolumn{1}{c}{ Показник } & 2010 & 2011 & 2012 & 2013 & 2014 & 2015 & 2016 \\
\hline Всього витрат, млн грн & 864,00 & 1120,00 & 1238,00 & 2441,72 & 2653,00 & 3688,30 & 4503,10 \\
у т.ч.: власні кошти, млн грн & 489,07 & 628,95 & 635,80 & 1801,15 & 2192,20 & 3290,10 & 4437,20 \\
питома вага, \% & 56,61 & 56,16 & 51,36 & 73,77 & 82,63 & 89,20 & 98,54 \\
Кошти державного бюджету, млн грн & 374,93 & 491,05 & 602,20 & 640,57 & 460,80 & 398,20 & 66,20 \\
питома вага, \% & 43,39 & 43,84 & 48,64 & 26,23 & 17,37 & 10,80 & 1,47 \\
\hline
\end{tabular}

Джерело: за даними Державного агентства лісових ресурсів України

За результатами господарсько-фінансової діяльності підприємств галузі у 2016 р. отримано 12355,4 млн грн чистого доходу від реалізації продукції (товарів, робіт, послуг), що на 1940,8 млн грн (19\%) більше, ніж у 2015 році. Чистий прибуток становив 597,2 млн грн, з якого 447,9 млн грн (75 \%) відраховано до державного бюджету.

На ведення лісового і мисливського господарства, охорону і захист лісів спрямовано 4503,4 млн грн, 3 них 4437,2 млн грн або 98,5 \% власних обігових коштів підприємств та 66,2 млн грн або 1,5\% - коштів державного бюджету. Однак, незважаючи на обмежене фінансування лісового господарства, а також складні соціально-економічні умови, економічна діяльність підприємств лісового господарства
України загалом впродовж досліджуваного періоду була успішною (табл. 3).

Згідно з положеннями діючого Лісового кодекcy (Forest code of Ukraine, 1994), основними функціями лісів $\epsilon$ екологічна та соціальна. Економічній складовій (тобто забезпечення деревиною лісової промисловості) не приділяється належної уваги.

Аналіз ведення лісового господарства за основними показниками показує, що з 2010 по 2015 рр. відбулося помітне їхнє зростання. Так, обсяги продукції, робіт та послуг лісового господарства зросли 3 4097,7 млн. грн. у 2010 р. до 10778,2 млн грн. у 2015 році. Заготівля ліквідної деревини збільшилась на 19,3\%, склавши у 2010 р. 16145,6, а в 2015 р. $-19267,7$ тис. $\mathbf{M}^{3}$. 
Обсяги продукції, робіт та послуг лісового господарства в Україні впродовж 2010-2015 рр.

\begin{tabular}{|c|c|c|c|c|c|c|c|}
\hline \multirow{2}{*}{ Показники } & \multicolumn{7}{|c|}{ Роки } \\
\hline & 2010 & 2011 & 2012 & 2013 & 2014 & 2015 & $2015 / 2010$ \\
\hline $\begin{array}{l}\text { Обсяги продукції (товарів та послуг) } \\
\text { лісового господарства (у фактичних } \\
\text { цінах), млн грн }\end{array}$ & 4097,70 & 5674,80 & 5911,60 & 6363,90 & 7739,90 & 10778,20 & 6680,50 \\
\hline Площа рубок, га & 4097,70 & 5674,80 & 417005,00 & 415420,00 & 382623,00 & 399296,00 & 395198,30 \\
\hline Заготівля деревини, тис. м³ & 18064,60 & 19746,20 & 19763,60 & 20340,60 & 20672,40 & 21924,20 & 3859,60 \\
\hline Заготівля ліквідної деревини, тис. м³ & 16145,6 & 17510,3 & 17506,7 & 18021,9 & 18333,2 & 19267,7 & 3122,10 \\
\hline в т.ч. від рубок головного користування & 7239 & 8011,7 & 7790,2 & 7839,9 & 8218,6 & 8391,8 & 1152,80 \\
\hline $\begin{array}{l}\text { в т.ч. від рубок формування } \\
\text { та оздоровлення лісів та інших заходів }\end{array}$ & 8906,6 & 9498,6 & 9716,5 & 10182 & 10114,6 & 10767,8 & 1861,20 \\
\hline Кількість лісових пожеж, од. & 3240,00 & 2526,00 & 2163,00 & 1113,00 & 2003,00 & 3813,00 & 573,00 \\
\hline $\begin{array}{l}\text { Площа лісових земель, пройдена } \\
\text { пожежами, га }\end{array}$ & 3668,00 & 1049,00 & 3479,00 & 418,00 & 13778,00 & 14691,00 & 11023,00 \\
\hline Згоріло та пошкоджено лісу на пні, м³ & 343840 & 11804 & 289291 & 2496 & 144694 & 170686 & -173154 \\
\hline $\begin{array}{l}\text { Збитки, заподіяні лісовими пожежами, } \\
\text { тис. грн }\end{array}$ & 26728,40 & 3215,90 & 56062,70 & 1376,20 & 51701,80 & 20164,50 & $-6563,90$ \\
\hline Площа відтворення лісів, тис. га & 70,10 & 72,40 & 70,10 & 67,70 & 58,00 & 60,40 & $-9,70$ \\
\hline
\end{tabular}

Джерело: за даними Державної служби статистики України

За зменшення загальної площі рубок лісу на 2,9 тис. га у 2015 р. порівняно з 2010 р., спостережено збільшення площі рубок головного користування на 5,5 тис. га, що загалом $є$ позитивним явищем.

Обсяг штучного відтворення лісів помітно зменшився (у 2015 р. порівняно з 2010 р. зменшився на 9,7 тис. га) як наслідок переходу підприємств на природне залісення зрубів.

Висновки. Втрата лісогосподарськими підприємства фінансової стабільності виявляе не лише негативні фінансово-економічні наслідки, але й соціальні та екологічні, негативно відображаючись на цінності деревини, погіршенні їі товарної і сортиментної структури. Тому реалізація комплексу заходів з упорядкування системи фінансування лісогосподарського виробництва сприятиме поступовому поліпшенню екологічної ситуації та стабільному забезпеченню вітчизняної промисловості деревиною.

Бюджетні видатки на лісову галузь $є$ одним із важливих інструментів впливу на іiі розвиток, оскільки основними цілями ведення лісового господарства $\epsilon$ відтворення лісів на не вкритих лісовою рослинністю землях, створення лісів на нелісових землях, догляд за насадженнями, охорона лісів від пожеж та лісопорушень, захист лісів від шкідників і хвороб, будівництво доріг лісогосподарського призначення, оплата праці, страхування, соціальна захищеність працівників. Перелічені напрямки діяльності фінансуються недостатньо, що значною мірою стримує розвиток та осучаснення лісового господарства. Зокрема, відсутність фінансування наукових досліджень не дає змоги повною мірою зрозуміти поточний вплив змін клімату на стійкість лісів та їх продуктивність, своєчасно виявити майбутні негативні впливи та розробити відповідні коригуючі заходи.

Одним із способів регулювання раціонального природокористування $\epsilon$ використання податків, які дають змогу вилучити частину ренти з метою ііі використання для фінансування потреб відтворення природних ресурсів та створення передумов для стимулювання ефективного та економного їх використання.

Існуюче податкове законодавство не дає змоги акумулювати частину податкових надходжень на спеціальних рахунках Держагентства, яке реалізує політику в галузі використання лісових ресурсів, що не дає можливості нагромаджувати інвестиційну базу відтворення природоохоронної інфраструктури та покращувати режим залучення ресурсів у відтворювальний процес. Вагомим стимулом до нарощення обсягів вторинної переробки й застосування технологій, які сприяють економії природної сировини, стало б суттєве збільшення нормативів плати за спеціальне використання природних ресурсів та розширення бази оподаткування.

Результатом державної стратегії розвитку лісової галузі має стати підвищення рівня життя та добробуту населення, як наслідок вдосконалення наповнення бюджету за рахунок податкових надходжень. Необхідним елементом в удосконаленні вищезазначеного процесу $є$ дослідження впливу 
фіскального механізму на розвиток лісового господарства.

\section{Бібліографічні посилання}

Antonenko, I. Ya. (2001). Ecological-economic assessment of the effectiveness of use and protection of forest resources (Doctoral dissertation, Council for the Study of Productive Forces of Ukraine of the National Academy of Sciences of Ukraine, Kyiv, Ukraine). Retrieved from https://www.irbis-nbuv.gov.ua/cgibin/irbis64r 81/cgiirbis 64.exe. (in Ukrainian).

Bakaleiko, I. V., \& Volynchuk, Yu. V. (2014). Organization of financial flows in the system of forest enterprises. Economic sciences. Series: Economics and Management, 11, 6-19 (in Ukrainian).

Bobko, A. M. (2014). Protection of land and land use in the field of forestry. Viche. 19. Retrieved from http:// www.viche.info/journal/4386 (in Ukrainian).

Conception of transition of Ukraine to steady development (1992). www.mns.gov.ua/laws/laws/ nuclear/92.htm Retrieved from http://www.mns.gov. ua/laws/laws/nuclear/92.htm (in Ukrainian).

Dubas, R. H. (2011). An estimation of efficiency of recreation of forest resources is basis of ecologically balanced forest use. The Journal of Zhytomyr State Technological University. Series: Economics, 4 (58), 214-217. (in Ukrainian).

Forest code of Ukraine (1994). zakon3.rada.gov.ual laws/show/3852-12. Retrieved from: http://zakon3. rada.gov.ua/laws/show/3852-12 (in Ukrainian).

Furdichko, O. I., Bobko, A. M. (2013). Land for forestry in ecological and economic terms in land management. Balanced nature management. 2-3, 5-13 (in Ukrainian).

Ilnytska-Hykavchuk, H., \& Rymar, M. (2006). Taxation in the system of financial provision of forestry development in the conditions of European integration. Herald of the National University of Water Management and Nature Management, 4, 408413 (in Ukrainian).

Khvesik, M. A., Shubaliy, O. M., \& Vasilik N. M. (2011). Integrated use of forest resource potential. Kyiv: DKS (in Ukrainian).

Savushchyk, M., Poliakova, L. \& Popov, M. (2001). Forest renewal and afforestation in Ukraine. Forest and hunting magazine, 2, 8-9. (in Ukrainian).

Shershun, M. Kh. (Eds.). (2012). Reformation of the forestry system in Ukraine is in the context of the European prospect of development. Kyiv: DIA (in Ukrainian).

Shvydenko, A. I. (2004). Forestry. Chernivtsi: Ruta (in Ukrainian).

Tunytsia, Iu. Iu. (2011). Natural economy and close to nature forestry: identity of concepts and opportunities for their mutual enrichment. Proceedings of the Forestry Academy of Sciences of Ukraine, 9, 14-20. (in Ukrainian).

Turkevich, I. V. (1977). Cadastral valuation of forests. Moscow: Forest Industry (in Russian).

\section{Анализ финансирования расходов предприятий Гослесагентства из государственного бюджета Украины}

\author{
А.И. Карпук' ' И. М. Лицур ${ }^{2}$
}

Исследована сущность и особенности механизма фискального регулирования, обоснованны научно-теоретические основы его влияния на обеспечение сбалансированного развития лесного хозяйства в системе фискальной политики природопользования.

Установлено, что снижение финансовой стабильности лесохозяйственных предприятий негативно влияет не только на финансово-экономическую, но и социальную, экологическую ситуацию, продуктивность лесных экосистем, приводит к ухудшению сортиментной структуры древесины, потерю ею конкурентоспособности на рынке. Основными причинами недостатка средств бюджетов различных уровней являются: низкое долевое участие собственных доходных средств, зависимость от государственного финансирования, отсутствие стимулов для дополнительного получения доходов и экономного расходования бюджетных средств. При эффективной организации внутриотраслевого взаимодействия возможно минимизировать бюджетную поддержку и успешно функционировать на основе самоокупаемости, одновременно увеличив поступления в бюджеты всех уровней

Раскрыто современное состояние фискального регулирования лесного хозяйства Украины и систематизированы показатели оценки влияния соответствующего механизма на лесохозяйственную деятельность. Усовершенствовано методический подход к оценке эффективности функционирования механизма фискального регулирования в обеспечении сбалансированного развития лесного хозяйства с применением комплекса инструментов, а именно: уровня отдачи собранных налогов, фискальной достаточности, налогоотдачи и интенсивности процессов лесовосстановления. Определены основные причины нехватки средств бюджетов различных уровней: низкое долевое участие собственных доходных средств, зависимость от государственного финансирования, отсутствие стимулов для дополнительного получения доходов и экономного расходования бюджетных средств. Проведено сравнение до-

\footnotetext{
Карпук Анатолий Иванович - действительный член Лесной академии наук Украины, доктор экономических наук, директор обособленного подразделения Национального университета биоресурсов и природопользования Украины «Боярская ЛОС», ул. Лесоопытная 12, г. Боярка, 08150, Украина. Тел.: 045-98354-61. E-mail: vp_nau_blds@ukr.net.

2 Лииур Игорь Николаевич - член-корреспондент Лесной академии наук Украины, доктор экономических наук, ведущий научный сотрудник Государственного учреждения «Институт экономики природопользования и устойчивого развития НАН Украины», бульвар Тараса Шевченко 60, г. Киев, 01032, Украина. Тел.: 044-486-40-25, + 38-096-438-34-75. E-mail: ilytsur@ ukr.net
} 
ходов и расходов Государственного лесного агентства Украины на реализацию соответствующих мероприятий и обеспечения экологического равновесия в пределах установленного использования лесных ресурсов и выявлены существенные недостатки в части финансирования отрасли.

Обоснована зависимость наполнения бюджета и дальнейшего процесса перераспределения доходов между бюджетами разных уровней, и, как следствие, сбалансированного развития лесного хозяйства, от объема налоговых поступлений и эффективности применения инструментов фискального регулирования. Для улучшения реализации лесной политики доказана необходимость улучшения наполнения бюджетов всех уровней, предусматривающих применение таких инструментов, которые являются наиболее действенными и не требуют дополнительных расходов из бюджета, с одной стороны, не снижая показателей деятельности лесохозяйственных предприятий - с другой .

Предложены концептуальные основы функционирования механизма фискального регулирования с учетом мирового опыта.

Ключевые слова: фискальное регулирование; лесохозяйствования; лесные ресурсы; налоговая нагрузка.

\section{Analysis of financing costs of the enterprises of State Forest Resource Agency from the state budget of Ukraine}

\section{A. Karpuk' ${ }^{1}$ I. Litsur ${ }^{2}$}

The essence and peculiarities of the fiscal regulation mechanism are studied. The scientific and theoretical bases of its influence on ensuring a balanced

Anatoly Karpuk - full Member of the Forestry Academy of Sciences of Ukraine, Doctor of Economics, Director Boyarska LOS National University of Bioresources and Nature Management of Ukraine, Forest Experimental st., 12, Boyarka, 08150, Ukraine. Phone: 045983-54-61. E-mail: vp_nau_blds@ukr.net.

Igor Litsur - Corresponding Member of the Forestry Academy of Sciences of Ukraine, Doctor of Economics, Leading Researcher State Institution "Institute for Environmental Economics and Sustainable Development of the National Academy of Sciences of Ukraine", Taras Shevchenko boulevard 60, Kyiv, 01032, Ukraine. Tel.: 044-486-40-25,+38-096-438-34-75. E-mail: ilytsur@ukr.net development of forestry in the system of fiscal policy of nature resource management are justified.

The state of fiscal regulation in the sphere under investigation has been analyzed. It is found that a decrease in the financial stability of forestry enterprises negatively affects not only the financial and economic situation, but also the social and environmental situation and productivity of forest ecosystems, leads to a deterioration of the timber assortment structure, and loss of its competitiveness on the market. The main reasons for the shortage of budget funds at various levels are: a low share of own revenues, dependence on public funding, lack of incentives for additional income generation and cost-effective spending of budget funds. With effective organization of intraindustry interaction, it is possible to minimize budget support and function on the basis of self-sufficiency and increasing revenues to budgets of all levels.

The present state of fiscal regulation of forestry in Ukraine is disclosed and the indicators of the impact of the relevant mechanism on forest management are systematized. The methodical approach to the assessment of the effectiveness of the functioning of the mechanism of fiscal regulation in ensuring a balanced development of forestry with the use of a set of tools has been improved, namely: the level of return of collected taxes, fiscal sufficiency, tax return and intensity of reforestation processes. The revenues and expenditures of the State Forest Agency of Ukraine for the implementation of relevant measures and ensuring ecological balance within the established use of forest resources compared and significant shortcomings in the financing of the sector revealed.

It is justified, the dependence of the filling of budgets, and the further process of income redistribution between budgets of different levels and, as a result, balanced development of forestry, on the volume of tax revenues and the effectiveness of the use of fiscal regulation instruments. It has been proved that to improve the forest policy implementation, it is necessary, first of all, to ensure the improvement of the filling of budgets at all levels, including the use of such tools that are most effective and do not require additional expenditures from the budget, on the one hand, and do not reduce the performance of forestry enterprises on the other.

Conceptual bases of the mechanism of fiscal regulation functioning taking into account world experience are proposed .

Key words: fiscal regulation; forestry; forest resources; tax burden. 